\title{
THE COLLECTIVE AGREEMENT FOR THE UNION SHOP
}

\author{
LEON M. DESPRES*
}

U

NKNOWN to the courts a half century ago, the "closed shop" or union shop contract has received increasing judicial attention, particularly during the last fifteen years. With union organization itself formerly illegal, the union shop contract was, of course, also illegal. With judicial acceptance of union organization, however, the judicial attitude toward the union shop contract has undergone an important and exceedingly interesting development, which it is the purpose of this article to trace.

At the outset, a preliminary question of terminology is posed. Like its counterpart "open shop," the term "closed shop" rings with overtones and conflicts; "open shop" and "closed shop" have become "but battle cries in the conflict between employers and labor organizations over the problem of unionization." Formerly the meaning of the terms "open shop" and "closed shop" was quite different from their present meaning. A "closed shop" was an unfair shop in which a union had forbidden its members to work; and an "open shop" was a shop in which a union permitted its members to work. Declaring a shop "open" was equivalent to calling off a strike or boycott." The change in meaning occurred about 1890 . Although perhaps first used by unionists, the term "closed shop" was seized upon by employers to obtain the greatest possible advantage in publicizing its unfavorable connotations. Trade unionists have often since condemned the term, saying that the only closed shop is the so-called "open shop" which is really closed to union members. "Open shop" and "closed shop" have thus become catchwords which obscure the underlying issues; and to avoid the use of those terms, this article will use the term "union shop,"

* Member of the Tllinois Bar.

I Leiserson, Closed Shop and Open Shop, 3 Encyc. Soc. Sci. 568 (I930). It is estimated that about three million of the nearly eight million organized workers in the United States are working under union shop conditions, Closed Shop and Check-off in Union Agreements, 49 Monthly Lab. Rev. 830 (1939).

2 Series XXIX, Johns Hopkins University Studies in Historical and Political Science, no. 3, Stockton, The Closed Shop in American Trade Unions I4 (IgIr).

3 Gompers, Annual Report to AFL Convention of rgo3, quoted in Gompers, Labor and the Employer II2 (1920). 
generally used by the United States Department of Labor's Bureau of Labor Statistics. ${ }^{4}$

The "closed shop" or union shop is now generally understood to be a shop in which each employee is required as a condition of continuing employment to be a member of a designated union. A union shop contract is an agreement between a union and one or more employers establishing the union shop. Thus, for example, the great coal miners' strike to achieve the union shop in the spring of 1939 was settled by the execution of an agreement between the United Mine Workers of America and most of the coal operators, providing in part:

It is agreed that as a condition of employment all employees shall be members of the United Mine Workers of America, except those exempt classifications of employment as provided in the contract.s

There are many variations in the form of the union shop contract, but the essence remains as stated in this provision.

\section{THE ECONOMIC BACKGROUND OF THE JUDICIAL DECISIONS}

The judicial treatment of the union shop contract can be understood only when it is considered in the light of the economic background of the past century and the practical incentives determining the attitudes of employer and employed toward the union shop contract. The concentration of capital and reduction of skill which began their development at the end of the eighteenth century reduced the isolated workingman to an insignificant unit and increased enormously the power, resources, and influence of the large employer. ${ }^{6}$ To remove competitive underbidding by laborers, to gain the strength of collective bargaining which comes with the creation of a reserve and the ability to withhold labor, and to secure a measure of control of market conditions in the field of labor, workingmen, although competitors with one another, formed unions; and there are now, according to one authority on labor relations, not less than seven principal classifications of shops on the basis of degrees of unionization:7

I. The closed anti-union shop, in which no union members are allowed to work. This is often referred to as the "open shop."

2. The preferential anti-union shop, where union members are occa-

4 See, e.g., Trade Agreements r927, Bureau of Lab. Statistics Bull. No. 468, at 2 (r928).

$s_{4}$ L.R.R. 379 (r939); for a description of various forms of union shop agreements see Closed Shop and Check-off in Union Agreements, 49 Monthly Lab. Rev. 830 (1939).

6 Blum, Labor Economics 373 (I925).

7 Daugherty, Labor Problems in American Industry 458-60 (I938). 
sionally tolerated, as long as they are decidedly in the minority and as long as the union is not engaged in active organizing.

3. The true open shop, where union and non-union employees work, without union recognition. Except as a temporary transitional condition, it usually exists only in classrooms or in the minds of theorizers, according to Daugherty. ${ }^{8}$

4. The shop where the employees are predominantly union members, and where there is recognition of the union. The railroads furnish an example of this type.

5. The preferential union shop where union members are hired first and laid off last.9

6. The union shop with an open union, where the employer is required to hire all available union members first, and where, if other persons are necessarily hired, they must become union members. Union membership is easy to obtain.

7. The union shop with a closed union where every employee must be a member of the union and where the union has substantially effective control over hiring policies by its rigid control over the admission of new members. This shop exists most widely where specialized skill is required and the productive process is still relatively untouched by the substitution of machinery, as in the printing industry.

The period during which labor unions have developed, from the end of the eighteenth century to the present, has been called a period of "free competition," and the concepts of freedom of competition prevalent at the beginning of the period have been generally appropriated by the courts and expressed as law. "Everyone has a right," said the Supreme Judicial Court of Massachusetts in $I 87 \mathrm{II}$, "to enjoy the fruits and advantages of his own enterprise, industry, skill and credit. $\mathrm{He}$ has no right to be protected

${ }^{8}$ See also Blum, Labor Economics $35^{8}$ (1925).

9 The preferential union shop contract, which provides that union members shall be preferred in hiring, laying off, and reinstating, leads rapidly to the almost exclusive employment of union members, Commons, Labor and Administration 90 (Igr3). It has received no substantially different judicial treatment from the union shop contract. It may be enforced by injunction in Georgia at the suit of the union (O'Jay Spread Co. v. Hicks, I85 Ga. 507, I95 S.E. 564 (1938)); it is equally objectionable with the union shop in Massachusetts (Folsom Engraving Co. v. McNeil, 235 Mass. 269, I26 N.E. 479 (I920)); and it has been held to come within the union shop proviso of the National Labor Relations Act ( 49 Stat. $45^{2}$ (I935), 29 U.S.C.A. $\$ \times 58$ (3) (Supp. x938)) in Peninsular \& Occidental Steamship Co. v. NLRB, 98 F. (2d) 4 II (C.C.A. $5^{\text {th }} 1938$ ), cert. den. 305 U.S. 653 (1938) (for a critique of this opinion see Inter-union Disputes in the Shipping Industry, 48 Yale L. J. ro (I939)); Waterman Steamship Co. v. NLRB, I03 F. (2d) I 57 (C.C.A. 5th I939), cert. granted October 9, I939.

xo Walker v. Cronin, 107 Mass. 555, 564 (1871). 
against competition; but he has the right to be free from malicious and wanton interference, disturbance or annoyance." And in I923, the Supreme Court of the United States through Justice Sutherland reiterated ${ }^{\text {II }}$ that "surely the good of society as a whole cannot be better served than by the preservation against arbitrary restraint of the liberties of its constituent members."

Under this doctrine, courts permitted freedom to men of enterprise and industry to amass concentrations of wealth and power which gave them great collective bargaining strength in their dealings with the workingmen who sought to sell their labor power. The courts extended so widely the freedom of such men to contract that not only were they permitted to enter into unassailable contracts for the "open" or non-union shop ${ }^{\mathrm{r2}}$ but the state and federal governments were declared to be powerless to affect this freedom by limiting legislation. ${ }^{13}$ Conversely, however, the courts first outlawed all agreements for combinations of workingmen, then outlawed the means of picketing and boycotts by which unions sought to gain their ends, and finally outlawed or refused to give complete effect to the contract for the union shop. ${ }^{x 4}$ The attitude of the courts was predominantly one of vigilance to protect employers and society against the union shop and the union shop contract and to protect employers in their right to contract for the non-union shop; but as union organization and the union shop contract established themselves in fact and exhibited certain characteristics beneficial to employers and to society, judicial treatment changed.

The union's desire for the union shop contract rests fundamentally on the wish to secure intactness of organization and complete acceptance of unionization by the employer, so that the union may enjoy freedom from anti-union discrimination by the employer and from underbidding by nonunion employees. ${ }^{x 5}$ The effective and complete organization which prevails in the successful union shop obviously tends to make the union able more effectively to obtain its ends of higher wages, shorter hours, satisfactory working conditions, sustained employment, and freedom from possible mistreatment. Union members feel also that all employees sharing the benefits obtained by union organization should share the expense

"Adkins v. Children's Hospital, 26I U.S. 525, 56I (1923).

12 Hitchman Coal \& Coke Co. v. Mitchell, 245 U.S. 229 (19r7).

${ }^{23}$ Adair v. United States, 208 U.S. I6I (Ig08); Coppage v. Kansas, 236 U.S. I (I9I5).

${ }^{24}$ Landis, Cases on Labor Law I-37 (I934).

${ }^{35}$ The Closed Shop, Nat'I Industrial Conference Board Studies in Personnel Policy No. I2, at 5 (r939). 
of the organization. The union shop contract has been likened to a tariff wall erected to protect the gains of past labor struggles. ${ }^{16}$ Furthermore, since the union shop contract is now generally understood to be an important goal of union activity, the union which has not achieved it is usually considered to have failed to achieve complete organizational success. The failure may, at times, be compensated for by other factors such as a high wage scale, great security of tenure, or such complete acceptance of unionization by the employer that conditions of employment are virtually equivalent to those in the union shop. Such compensating factors exist in the cases of many of the railroad brotherhoods. ${ }^{\mathbf{} 7}$

The union shop contract is not always an unmixed blessing to the successful union. By removing the incentive to keep continuously prepared for possible organizational attack by an employer, it may make a union less vigilant and thereby untrained and unfit for a later contest for better conditions. By creating a stable dues paying organization, it tends to enlarge the opportunities for official position within the union, and thereby often assists materially in subsidizing a union bureaucracy which sometimes grows apart from the membership. Some union leaders have even declared that they would prefer a true open shop, if it were possible, to the union shop. ${ }^{18}$

The employer's opposition to the union shop contract comes principally from antipathy to collective bargaining in general ${ }^{19}$ or from a belief that the strength which comes from the union shop will be used as a weapon to force greater economic concessions later. ${ }^{20}$

The union shop contract is by no means always a detriment to the employer, nor is the attitude of employers exclusively one of unrelenting opposition. By removing the union's fear of attack, the union shop contract permits the substitution of a degree of union-employer collaboration often directly profitable to the employer in terms of operating costs. It frequently tends to eliminate factional strife, periodic stoppages, and demands for compensatory concessions. These advantages have been widely recognized by many employers, who have entered into union shop contracts. ${ }^{2 x}$ Furthermore, employers are often vitally interested in extending the union shop to competitors in order to establish substantially uniform

\footnotetext{
${ }^{16}$ Commons, Labor and Administration 88 (Igra).

${ }^{17}$ Cummins, The Labor Problem in the United States 306 (1932).

${ }^{8}$ Blum, Labor Economics 363 (I925).

${ }^{19} 4$ Commons, History of Labor in the United States 49 I (I935).

${ }^{20}$ The Closed Shop, op. cit, supra note 15, at Ix.

2x Ibid., at $x$; Feller and Hurwitz, How to Deal with Organized Labor II (I937).
} 
wage rates. Thus the employer who already has the union shop may become an enthusiastic champion of the union shop for other employers as a means of creating stability by lifting wage rates and other working conditions out of competition.

The social advantage of the union shop contract lies in the industrial peace which it tends to promote. When strong workingmen's and employers' organizations establish suitable voluntary machinery for the settlement of differences, the chances of eliminating work stoppages and maintaining industrial peace are tremendously increased. ${ }^{22}$ It is true that when bargaining between strong organizations fails, the result may be an industrial war of greater proportions than would otherwise be the case; but the better organized a union is, the smaller is the chance that a quarrel will mature into a strike. ${ }^{23}$ This advantage of the union shop was certainly implicitly recognized by the Supreme Court in its approval of the industrial peace attained by the Amalgamated Clothing Workers of America in the New York men's clothing market. ${ }^{24}$ Strong unions with union shop contracts often tend also, at least in their immediate effect, to raise wages, shorten hours, and increase efficiency, both in the individual plant and in the industry. ${ }^{25}$ This factor was also commented on by the Supreme Court in connection with the Amalgamated Clothing Workers of America. Certain social disadvantages of the union shop contract occur in fields where the existence of special skills sometime permits the union to acquire apparently complete control of the labor supply and thereby to restrict the influx of new workers, fix an inordinately high wage, and resist technical improvements. Such restrictive activity tends to create price bottlenecks in times of prosperity and to aggravate unemployment in times of depression. Unions and employers sometimes enter into strange alliances, having price fixing as well as collective bargaining aspects, and such alliances often result in double sided monopolies. But not every restrictive provision constitutes an undesirable monopoly..$^{26}$ In fact, by the very nature of labor, a closed union can never gain as complete a monopoly as other forms of monopoly. It has been doubted wheth-

${ }^{2}$ Blum, Labor Economics 24r (1925); I Marshall, Elements of Economics 406 (2d ed. I896); Pigou, Unemployment I3I (I9I3); see testimony of Louis D. Brandeis in S. Doc. 4r5, at 7681,64 th Cong. Ist Sess. (rgr6) (Final Report of Committee on Industrial Relations), quoted in 50 Harv. L. Rev. Io7I, I075, note I4 (I937).

23 Marshall, op. cit. supra, note 22.

${ }^{24}$ NLRB v. Friedman-Harry Marks Clothing Co., zor U.S. 58, 74 (1937). See Abelow, The Closed Shop in New York, 7 Brooklyn L. Rev. 459, 460 (r938).

${ }^{25}$ Marshall, op. cit. supra note 22, at 394, 4I8.

${ }^{26}$ Clark, Social Control of Business 447 (I926). 
er any closed union could be successful for any substantial period without the collusion of employers. ${ }^{27}$ Furthermore, in the great unskilled trades and in industries subject to foreign competition, unions can not approach an effective degree of monopoly.$^{28}$ The ease with which persons can enter the unskilled trades would prevent a union from obtaining control of the labor supply unless it included every potential worker. The presence of a foreign product ready to compete with the product of a domestic industry would sharply limit the effectiveness of union control of domestic labor. The union could obtain no permanent concession beyond the point at which the foreign product would be cheaper. Courts which reject the union shop contract often rest their rejection on the disadvantages of a union labor "monopoly" both in its general social effect and in its particular effect on individuals who are excluded from the union or who have not joined it. There has been little tendency in judicial opinions to differentiate the "monopolies" of a closed union which has acquired a union shop contract of a highly restrictive nature in a field requiring special skill and the open union which has achieved a union shop contract in an unskilled or competitive field where a genuinely effective monopoly is virtually unattainable. Nevertheless, this differentiation seems to have been implicitly recognized in some of the most recent decisions.

The earliest judicial attitudes toward the union shop contract coincided with the opposition of employers and the general objection to the closed union in fields requiring special skill. The latest judicial attitudes have coincided with the favorable attitudes of many employers and the general approval of results obtained when the union shop contract is made with an open union in an unskilled or competitive field. In the development of the union shop contract, the National Labor Relations Act must be considered as a legislative landmark evidencing an exceedingly important change in the general attitude. It indicates a wide acceptance of the principle of the voluntary union shop contract and creates new requirements designed not to prevent the union shop contract but to create assurances that the contract shall be executed by a labor organization which is actually the designated representative for all the employees involved. ${ }^{29}$ It would seem that only such free labor organizations could have the strength required to promote the industrial peace and avoid the monopolistic exclusion which have constituted respectively the recognized social gain and evil of the union shop contract in this country. The importance of the act

27 Blum, Labor Economics 36r (1925).

${ }^{28}$ Marshall, op. cit. supra note 22 , at $4{ }^{\mathrm{r}} 4^{-\mathrm{I}} 5$.

29 See pp. 44-6 infra. 
lies, of course, not only in the fact of its enactment ${ }^{30}$ but in its complete approval by the Supreme Court despite the court's earlier and unequivocal insistence, qualified only by a dictum in $1930,{ }^{3 \mathrm{I}}$ on judicial protection against any legislative interference with employers' anti-union contracts. It is significant that the court's approval on April $\mathrm{x} 2, \mathrm{I} 937 \mathrm{i}^{32}$ came after an unparalleled unionization of unskilled workers.

\section{THE DEVELOPMENT OF THE JUDICIAL ATTITUDE TOWARD THE UNION SHOP CONTRACT}

In cases dealing with the union shop contract, courts have not written economic treatises on the union shop. The expression of judicial attitude has been connected with discussions of specific legal questions. The following are the most important questions which the courts have formulated as vehicles for the discussion of their attitude toward the union shop contract: (I) whether all picketing is unlawful if engaged in to compel execution of the union shop contract; (2) whether an employee who is discharged by operation of the union shop contract has a cause of action against the union; (3) whether a union shop contract is in unlawful restraint of trade; (4) how the union shop contract, once accepted, will be enforced; and (5) what privilege against interference is conferred on the employer party to the union shop contract.

I. At the outset, attention should be directed to the phenomenon of the doctrine, which prevails in some jurisdictions, that striking, picketing, or boycotting which is otherwise lawful will be enjoined if engaged in to compel the execution of a union shop contract. This doctrine is applied in some cases where the proposed union shop contract would, if executed, be declared to be valid and enforceable. ${ }^{33}$ Of course, if the proposed union shop contract would be invalid and unenforceable, we should not be astonished to find a court enjoining striking, picketing, and boycotting to obtain the proposed invalid agreement. Many opinions which discuss the validity of union shop contracts were rendered in cases

${ }^{30}$ Legislative bodies have usually been more responsive than courts to the new developments in the field, Blum, Labor Economics 72 (I925).

3r Texas \& N.O. R. v. Brotherhood, 28r U.S. 548, 570 (r930).

${ }^{32}$ NLRB v. Jones \& Laughlin Steel Co., 301 U.S. I (I937); NLRB v. Fruehauf Trailer Co., 3or U.S. 49 (I937); NLRB v. Friedman-Harry Marks Clothing Co., 301 U.S. 58 (1937); Associated Press v. NLRB, 3 or U.S. 103 (I937); Washington, Virginia \& Maryland Coach Co. v. NLRB, 30r U.S. ${ }_{42}$ (1937).

33 Sayre, Labor and the Courts, 39 Yale L. J. 682, 695-9 (I930); Int'I Ticket Co. v. Wendrich, r22 N.J. Eq. 222, r93 Atl. 808 (1937), aff'd r23 N.J. Eq. 172, I96 Atl. 474 (r938); Heitkemper v. Central Labor Council, 99 Ore. I, r92 Pac. 765 (Ig2r); Webb v. Cooks', Waiters' \& Waitresses' Union, 205 S.W. 465 (Tex. Civ. App. I9I8). 
involving only striking, picketing and boycotting to obtain a proposed invalid agreement. But those courts which proscribe activities looking toward a union shop contract and which later recognize the contract's validity when executed explain simply that the union's purpose of inflicting injury on the employer by striking, picketing, or boycotting is not excused by the motive of obtaining the union shop contract. ${ }^{34}$ In other words, although such courts will enforce the union shop contract once an employer has freely executed it, they will protect employers in general from certain kinds of union pressure designed to compel them to execute it. The general tendency to accept and enforce the union shop contract has led courts away from holding such activities to be unlawful. The Supreme Court of Pennsylvania, which formerly was deemed to hold such views, ${ }^{35}$ changed its position in I933, explaining that the union's "primary aim was the protection of the employment of their members at the union rate of wage, while the means employed involved as a secondary purpose the injury of appellee's patronage." ${ }^{36}$ In the absence of a statute specifically authorizing peaceful picketing ${ }^{37}$ courts will be quick to enjoin peaceful picketing or boycotting to compel execution of a union shop contract which would cover a working employer. ${ }^{38}$ It should be recalled, however, that in such cases the relative bargaining strengths of the employer and the union may be quite different from the historic situation of a strong employer and defensive employees.

Lately, a number of courts have denied unions the right to picket for the union shop contract in cases where no recent or present employee is a member of the union. ${ }^{39}$ The courts explain that since no labor dispute is involved between an employer and his employees, there is no privilege to picket. Doubtless these cases reflect a judicial desire to free employers generally from pressure to execute the union shop contract under such circumstances, for no court has yet, independently of statute, held a union

${ }_{34}$ E. g., Heitkemper v. Central Labor Council, 99 Ore. I, 20, 192 Pac. 765,77 (1921).

35 Sayre, op. cit. supra note 33, at 696 .

${ }^{36}$ Kirmse v. Adler, 3 II Pa. 78, 85, I66 Atl. 566, 569 (I933).

37 See Senn v. Tile Layers' Union, 3or U.S. 468 (1937).

${ }^{38}$ Hughes v. Kansas City Motion Picture Machine Operators, 282 Mo. 304, 22I S.W. 95 (1920); Parker Paint \& Wall Paper Co. v. Local Union No. 813, 87 W. Va. 63I, ro5 S.E. 9 Ir (I92I).

${ }^{39}$ Swing v. AFL, 372 IIl. 9r, 22 N.E. (2d) 857 (r939); Keith Theatre v. Vachon, 134 Me. 392 , 187 Atl. 692 (1936), annotated in Supplement (1937) to Landis, Cases on Labor Law (I934); Simon v. Schwachman, r8 N.E. (2d) I (Mass. I938); Lyle v. Amalgamated Meat Cutters \& Butchers Workmen of North America, I24 S.W. (2d) 7or (Tenn. I939); Safeway Stores v. Retail Clerks' Union, 184 Wash. 322, 5 I P. (2d) 372 (I935). 
shop contract invalid solely because the union was not the designated representative of the employees; nevertheless the cases also reflect in part a new attitude of which the National Labor Relations Act is legislative evidence,,$^{40}$ namely that the social advantages of the union shop contract can be obtained only if the union is the properly designated representative of the employees.

2. The courts have been most generous to the non-member employee who is found to have been discharged by operation of the employer's obligation under the union shop contract, and the number of cases of this category carried to courts of last resort seems to indicate that more substantial interests may at times have spoken through the pleadings of the nonmember plaintiff. The factual situations are generally uniform and simple: union members refuse to work or threaten to refuse to work with non-members; the employer and the union enter into an agreement for the union shop; employees who are not or do not become members of the union are refused employment. Although the discharge is effected by the employer and not by the union and although it is pursuant to a voluntary contract which the employer has executed with the union, liability for such discharges has been imposed on unions and not on employers. It is explained that since the employment is "at will," the employer has the right to discharge the worker at any time. Sometimes the decision is based on the "monopolistic" character of the union shop contract.41 If monopoly is really the gist of the action, the employer is a joint tort-feasor; yet no discharge case is found holding the employer liable. Most courts which impose a liability on the union explain that the union was motivated by "malice" or a wanton desire to interfere with the plaintiff's employment and to procure his discharge, that the union's conduct was wholly "unjustified," or that the union "compelled" the employer to discharge the plaintiff. ${ }^{42}$ Some courts have refused to impose liability, saying that the union and the employer are free to contract and that the union acted not for the injury of the discharged plaintiff but for the legitimate advancement of its own interests. ${ }^{43}$ Incidentally, some courts have denied re-

40 See pp. 44-6 infra. ${ }^{4}$ See pp. 36-4I infra.

${ }^{42}$ Sutton v. Workmeister, 164 Ill. App. 105 (I9II), which is probably erroneous, particularly in view of Kemp v. Division No. 24r, 255 Ill. 213, 99 N.E. 389 (x9I2); Lucke v. Clothing Cutters' \& Trimmers' Assembly, 77 Md. 396, 26 Atl. 505 (I893); Carter v. Oster, I34 Mo. App. I46, II2 S.W. 995 (I908); Clarkson v. Laiblan, x78 Mo. App. 708, I6r S.W. 660 (I9I3); Erdman v. Mitchell, 207 Pa. 79, 56 Atl. 327 (1903).

${ }^{43}$ Clemitt v. Watson, $x_{4}$ Ind. App. $3^{8,} 42$ N.E. $3^{67}$ (I895); Davis v. United Portable Hoisting Engineers, 28 App. Div. 396, 5 I N.Y. Supp. 180 (1898); Tallman v. Gaillard, 27 Misc. 114, 57 N.Y. Supp. 419 (I899); Kissam v. United States Printing Co., xg9 N.Y. 76, 92 N.E. 214 (rgro); Roddy v. United Mine Workers, 41 Okla. 621, 139 Pac. I26 (19I4); Local Branch 
covery to the plaintiff because his employment was at will; $;^{44}$ but the grounds of these decisions seem incorrect since it is now established that if interference with employment is actionable, the action is not defeated solely because the employment is at will. ${ }^{45}$ The courts which have refused to impose a liability for the discharge of non-members recognized almost explicitly under the surface of the judicial expressions that the union shop contract had become a legitimate aim of unions and that the courts would not punish unions for pursuing it. On the other hand the foreseeable and actual effect of the decisions imposing a money penalty on the unions was to weaken the defendant unions by the financial loss, to deter other unions to some extent from seeking the union shop, and to encourage unions which obtained the union shop to open their doors to new members. Furthermore, by providing a basis for injunctive relief, the doctrine was used to extend judicial restraint of union activity looking toward the achievement of the union shop..$^{6}$ To the extent that the decisions exercised judicial restraint upon the union shop, they continued the judicial restriction of labor organization commenced in the eighteenth century; however, to the extent that they provided an incentive to keep unions open to new members, they may have furnished a corrective to restrictive tendencies within unions.

A distinction might well be made in these cases between the discharged employee who has been unreasonably excluded from union membership and the discharged employee who has refused to join the union of his fellows. This question has occupied the courts' attention but has not controlled decisions. One court which imposed liability stressed the unreasonably high union initiation fee demanded of plaintiffs; ${ }^{47}$ another stressed the union's continued exclusion of the plaintiff. ${ }^{48}$ A Massachusetts decision refusing recovery emphasized that the plaintiff had never applied for admission to the union and that "by having as a part of its policy 'the custom' of not refusing membership to workmen who wish to join, such a

No. 248 v. Solt, 8 Ohio App. 437 (Igr8); Underwood v. Texas \& P. R., 178 S.W. $3^{8}$ (Tex. Civ. App. I9r5).

44 Harmon v. United Mine Workers, I66 Ark. 255, 266 S.W. 84 and III9 (I924); Cusumano v. Schlesinger, 90 Misc. 287, 152 N.Y. Supp. I081 (1915).

45 Truax v. Raich, 239 U.S. 33, 38 (Igr5); Moran v. Dunphy, I77 Mass. 485 , 59 N.E. 225 (IgOI).

${ }_{46}^{6}$ E.g., Erdman v. Mitchell, 207 Pa. 79, 56 Atl. 327 (1903).

47 Fairbanks v. McDonald, 219 Mass. 29I, 106 N.E. I000 (Igr4).

${ }^{8}$ Lucke v. Clothing Cutters' \& Trimmers' Assembly, 77 Md. 396, 26 Atl. 505 (I893). 
union avoids subjecting itself to this criticism" of refusing membership to competent persons.49 One court even strained the interpretation of a union shop contract to read into it a provision requiring admission into membership of all existing employees..$^{50}$ The following statement of ViceChancellor Bigelow, buttressed by a quotation from the late Chief Justice Taft, probably represents the present rationale of most courts:

.... Labor unions may be divided into two groups. In that which includes defendant, the union is an exclusive club, run for the benefit of its members and those fortunate persons whom it may elect. Its policies are baldly selfish. The other group comprises those unions which welcome to their ranks all good men in the same line of work who will submit to the common discipline. They believe with Chief Justice Taft, "It is helpful to have as many as may be in the same trade in the same community united, because in the competition between employers they are bound to be affected by the standard of wages of their trade in the neighborhood. Therefore, they may use all lawful propaganda to enlarge their membership and especially among those whose labor at lower wages will injure their whole guild." ${ }_{5 x}$ While the policies of such unions are selfish, as are those of all business organizations, still they are so far enlightened that they seek to aid their members by helping all workers in their trade who will join with them. They make contracts for exclusive employment of union men, not to create an artificial shortage in the labor market, but in order that there be no discrimination against union men; and that all the employees may share the financial burden which is an incident of organization, and so as to ensure a united stand in negotiations with the employer. ${ }^{2}$

Although unions as voluntary associations may make their own admission rules, ${ }^{53}$ it would seem exceptionally important to make provision, perhaps in the union shop contract itself, that the union be kept open to new persons available for employment and seeking membership. This should do much to avoid the objection of courts adopting the view of Vice-Chancellor Bigelow, but may not avoid the penalties imposed by courts which cling to the older view restricting the union shop contract and penalizing the union for all discharges. Once the employee has joined the union, he is thereafter bound by its lawful workings ${ }^{54}$ even though he

49 Shinsky v. O'Neil, 232 Mass. 99, 104, I2I N.E. 790, 792 (19r9).

${ }^{50}$ Dorrington v. Manning, C.C.H. Lab. Law Serv. $\$ I8322 (Pa. Super. Ct. I939).

5x American Steel Foundries v. Tri-City Central Trades Council, 257 U.S. r84, 209 (1921).

52 Wilson v. Newspaper \& Mail Deliverers' Union, I23 N.J. Eq. 347, 349, I97 Atl. 720, $72 I$ (I938).

53 Burke v. Monumental Division No. 52, 286 Fed. 949 (D.C. Md. I922), app. dism. 270 U.S. 629 (1926); Zaat v. Bldg. Trades Council, $1_{72}$ Wash. 445, 20 P. (2d) 589 (1933).

54 Ryan v. Hayes, 243 Mass. I68, I37 N.E. 344 (I922); O'Keefe v. Local 463, 277 N.Y. 300 , 14 N.E. (2d) 77 (1938); Connors v. Juilliard \& Co., C.C.H. Lab. Law Serv. 1 r8383 (N.Y. S. Ct. 1939). 
may thereby be deprived of employment; hence the principal reason for the importance of the many suits, not discussed here, ${ }^{55}$ seeking to modify or set aside union expulsions or rules.

Recognizing that there may be a distinction among discharges of nonmember employees, Massachusetts has evolved a doctrine which serves to continue the verbal confusion of the opinions. If the union is found in fact to have acted to injure the non-member employee without justification, it is liable for damages. ${ }^{56}$ On the other hand, if the purpose of the union shop contract is merely to give all the employer's work to the members of the union, it is valid. ${ }^{57}$ The distinction has been discerned by only one court outside of Massachusetts; and it was rejected. $5^{8}$ There is really no difference in fact between the two situations defined by the Massachusetts courts. The doctrine bears little relationship to the actualities of the union shop contract discussed at the beginning of this article; nor has its application been consistent.59 It appears that in Massachusetts, unions which succeed in negotiating the union shop agreement first have the employer discharge all employees, then complete the contract, and then have the employer re-employ the union members. ${ }^{60}$ Thus the practical effect of the decision upholds the executed union shop contract. It can be said in general that the Massachusetts courts have proceeded from early hostility to the union shop contract to acceptance of many of its features, ${ }^{6 x}$ and now, under the Massachusetts Labor Relations Act ${ }^{62}$ to regulation of the union shop in the interests of assuring workers' freedom of association.

3. Much of the judicial discussion of the union shop contract has been directed to determining in each case whether the contract creates a "monopoly." In this field, the word "monopoly" has become a strong competitor of "malice" as a preferred container of the courts' ratiocinative processes. The Restatement of the Law of Contracts cautiously sug-

ss See Oakes, Organized Labor and Industrial Conflicts $5 \mathrm{I}-80$ (I927).

${ }^{56}$ Berry v. Donovan, I88 Mass. 353, 74 N.E. 603 (1905); Fairbanks v. McDonald, 2I g Mass. 29I, I06 N.E. I00o (I9I4); Shinsky v. Tracey, 226 Mass. 2I, xx4 N.E. 957 (I9I7); Smith v. Bowen, 232 Mass. I06, I2I N.E. 8I4 (I9Ig).

57 Hoban v. Dempsey, $27_{7}$ Mass. I66, I04 N.E. $7 x_{7}$ (IgI4); Shinsky v. O’Neil, 232 Mass. 99 , I2x N.E. 790 (I9Ig).

${ }^{58}$ Kemp v. Division No. 24I, 255 Ill. 213, 249, 99 N.E. 389, 403 (Igr2). See Sharp and Gregory, Social Change and Labor Law IOI (1939). (r932).

59 See The Strike for the Closed Shop: Massachusetts Precedents, 45 Harv. L. Rev. I226

${ }^{60}$ Landis, Cases on Labor Law 378 (r934).

$6 \times$ Harv. L. Rev., op. cit. supra note 59 , at $\times 228$.

${ }^{62}$ Mass. Ann. Laws (Supp. 1938) c. I5० (A), $\$ 4$ (3). 
gests that "a restraint of trade is unreasonable, in the absence of statutory authorization or dominant social or economic justification, if it .... (c) tends to create, or has for its purpose to create, a monopoly, or to control prices or to limit production artifically." ${ }^{3}$ Not every restriction or accumulation of control is an unreasonable or unlawful monopoly, ${ }^{64}$ and the criteria for determining the unlawfulness of the union shop contract must depend on the "social or economic justification" suggested by the restatement. The courts have not generally considered the "social or economic" factors with the explicitness which the restatement's definition seems to require.

That the union shop contract may be unenforceable for being in unlawful restraint of trade has ample historic precedent. Formerly all union activities were considered to be in such serious restraint of trade that it was only in 1842 that an American court admitted the non-criminal nature of an agreement by union workingmen to strengthen their union by refraining from working with non-members. ${ }^{65}$ While enterprisers were free to acquire large plants, to hire and discharge at will, and to withhold employment from whomever they chose, courts were simultaneously condemning unions in certain cases for creating "monopolies" and using the union shop contract "maliciously" to deprive persons of a livelihood. However, those courts which have refused to hold union shop agreements to be monopolistic have emphasized the freedom of the parties to contract, the tendency of the contract to promote industrial peace, and the dominant desire of the union to further its own interests, to obtain employment and to secure protection from discrimination. Differences of geography and of time bring different results, reflecting varying judicial willingness to approve the union shop contract. Connecticut has held "monopolistic" a union shop contract covering all but two hat factories in Danbury. ${ }^{66}$ New Jersey has held the union shop contract to be "monopolistic" when covering the employees of the following enterprises: fifteen hat factories in five towns; ${ }^{67}$ the Building Trades Council and the Building Trades Employers' Association of New York City, including nearly all the build-

${ }_{63}$ Rest., Contracts $\$ 515$ (1932).

64 United States v. United States Steel Co., 25I U.S. 4 I7 (I920).

6s Commonwealth v. Hunt, 4 Metc. (Mass.) III (I842).

${ }^{66}$ Connors v. Connolly, 86 Conn. 64I, 86 Atl. 600 (I9I3); but Connecticut did not reach a similar conclusion as to the hat manufacturers' later agreement to operate their factories as open anti-union shops, Associated Hat Manufacturers v. Baird-Unteidt Co., 88 Conn. 332, 91 Atl. 373 (rgr4).

67 Brennan v. United Hatters of North America, 73 N.J. Law 729, 65 Atl. I65 (Igo6). 
ing contractors of New York City; ${ }^{68}$ all fifteen dealers in lumber and mason materials in Hudson County; ${ }^{69}$ fifty-two out of eighty furniture upholsterers in the Newark metropolitan area $;^{70}$ the only magazine mailing shop in Newark $;^{7 \mathrm{x}}$ a retail furniture store in Newark $;^{72}$ but not the twenty-five to thirty employees of the polishing department of a plating company. ${ }^{73}$ The New Jersey doctrine is so extreme that it indicates a hostile attitude to the union shop contract in general, aside from the specific aspect of "monopoly." A union shop agreement covering an entire city street railway was held "monopolistic" for Cleveland, Ohio, ${ }^{74}$ and for Akron, Ohio, ${ }^{75}$ but not for Des Moines, Iowa. ${ }^{76}$ In New York, the Court of Appeals held "monopolistic" a union shop contract with the Ale Brewers Association of Rochester, presumably covering all the ale breweries in the city, ${ }^{77}$ and another union shop contract covering the carpenters of nearly every prominent building contractor in New York City. ${ }^{78}$ In the later New York cases, we find union shop agreements sustained as reasonable restraints of trade although they cover substantially the entire important cloak and suit industry of New York City ${ }^{79}$ and ninety-eight per cent of all the fur workers in New York City. ${ }^{80}$

The most important recent decision dealing with this question is Williams v. Quill, ${ }^{8 \mathrm{x}}$ decided in 1938 . To gain insight into all the decisions, the opinion of Williams v. Quill should be carefully considered against the

${ }^{68}$ Lehigh Structural Steel Co. v. Atlantic Smelting \& Refining Works, 92 N.J. Eq. I3I, III Atl. 376 (I920).

${ }^{69}$ Baldwin Lumber Co. v. Local 560, 9I N.J. Eq. 240, Io9 Atl. I47 (1920).

${ }_{70}$ Upholsterers, etc. Int'l Union v. Essex Reed \& Fibre Co., I2 N.J. Misc. 637, I74 At1, 207 (I934).

${ }_{7 x}$ Wilson v. Newspaper \& Mail Deliverers' Union, I23 N.J. Eq. 347, I97 Atl. 720 (r938).

72 Canter Sample Furniture v. Retail Furniture Employees Local No. rog, I22 N.J. Eq. 575, I96 Atl. 2ro (r937).

${ }^{3}$ Four Plating Co. v. Mako, r22 N.J. Eq. 298, 194 Atl. 53 (I937).

${ }_{4}$ Polk v. Cleveland R., 20 Ohio App. 3 I7, I5I N.E. 808 (1925).

${ }^{75}$ Scaggs v. Transport Workers Union, 4 L.R.R. 58ir, C.C.H. Lab. Law Serv. If 18357 (Ohio Ct. of App. I939).

${ }^{76}$ Des Moines City R. v. Amalgamated Ass'n, 204 Iowa II95, 213 N.W. 264 (1927).

77 Curran v. Galen, 552 N.Y. 33, 46 N.E. 297 ( $(x 897)$.

.${ }^{8} \mathrm{McC}$ Cord v. Thompson-Starrett Co., I29 App. Div. I30, II3 N.Y. Supp. 385 (r907), aff'd 198 N.Y. 587,92 N.E. Iogo ( $x 9$ ro).

79 American Cloak \& Suit Manufacturers Ass'n v. Brooklyn Ladies Garment Manufacturers Ass'n, 143 Misc. 319, 255 N.Y. Supp. 614 (I93I).

${ }^{80}$ American Fur Manufacturers Ass'n v. Associated Fur Coat \& Trimming Manufacturers, I6r Misc. 246, 29I N.Y. Supp. 6ro (I936), aff'd 25I App. Div. 708, 298 N.Y. Supp. 392 (I937).

${ }^{81} 277$ N.Y. I, I2 N.E. (2d) 547 (1938), app. dism. for want of a final judigment 303 U.S. 62 I ( 1938$)$. 
background of its predecessor cases. In 1897 a discharged non-member employee claimed damages against a brewery workers' union for his discharge following a union shop contract which covered presumably all the ale brewers of Rochester, New York. The Court of Appeals held, in Curran v. Galen, ${ }^{82}$ that while workingmen had the right to organize into unions, they might not deprive people of employment by unlawful acts; and that the union shop contract which required each brewery employee to join the union within four weeks of his initial employment operated unlawfully to keep persons from working at the trade. That the union was required by the contract to keep itself open for new members who might join and continue working was not commented upon. That the union shop contract might promote industrial peace was commented upon and rejected as insufficient justification. In I905, a union sued an employer upon a note given to secure performance of a union shop contract. The employer contended that the agreement was unlawful. The court rejected the contention, saying in Jacobs $v$. Cohen ${ }^{83}$ that the parties had contracted freely, that the union was motivated by a proper desire to promote its own interests, and that no monopoly had been created. Justice Vann dissented vigorously and maintained that both employer and employed had placed themselves under the domination and monopoly of the union. "Would a court of equity," Justice Vann asked rhetorically, "enforce such an agreement by a decree for specific performance? Would it command the employer to discharge workmen simply because they refused to join the union? Would it restrain him from employing competent men because they were not members of the union?"84 The answer was furnished by the Appellate Division in 1923 in the case of Schlesinger $v$. Quinto ${ }^{85}$ where such injunctive relief was granted, and where, although the union shop in question covered half the women's garment industry in New York City, no question as to "monopoly" was raised. Finally, in Williams v. Quill ${ }^{86}$ six non-union employees sought to enjoin the Transport Workers Union and the employers from entering into a union shop contract covering the main transit and street railroad lines in New York City. The court concluded that the union members' purpose was not to injure plaintiffs, but to advance their own interests, "to meet on even terms their employers in present or future negotiations." Answering the historic contention that a union shop con-

${ }^{82}{ }_{5} 2$ N.Y. 33,46 N.E. 297 (1897). $\quad 8_{3} 183$ N.Y. 207,76 N.E. 5 (I905).

84 Jacobs v. Cohen, I83 N.Y. $207,222,76$ N.E. 5, II (Ig०5).

8520 I App. Div. 487, I94 N.Y. Supp. 40 I (I922).

${ }^{36}{ }_{277}$ N.Y. I, I2 N.E. (2d) 547 (I938), app. dism. for want of a final judgment 303 U.S. 621 (1938). 
tract covering an entire trade in a city or community is an unlawful monopoly (which the court might easily have determined to adopt, had it so desired), the court stated:

Carrying out this doctrine to its logical conclusion, all such contracts would be illegal where the employer in a village or town or small community was the only one in that particular line of business. We think that this distinction is not justified, and that if there be an evil in the monopoly of the labor market in a particular industry by labor organizations it is a matter to be considered by legislatures and not by the courts, for the reason that there are two sides to the question - the other side being that the labor organizations, through this means of contracting and negotiating, are enabled to strengthen their representative bodies and to effectuate collective bargaining. ${ }^{87}$

The court mentioned that the New York anti-trust statute excludes labor unions from its scope, but the importance of Williams v. Quill lies in the court's refraining from condemning the contract as "monopolistic" under general law. The court expressly pointed out that in Curran v. Galen the union was motivated by a desire to injure the plaintiffs, whereas in Williams v. Quill, the union sought primarily to advance its own interest. Nevertheless, Curran v. Galen must be deemed to be overruled, for if the union shop contract involved there was an unlawful monopoly, so a fortiori would be the much more extensive contract of Williams $v$. Quill. What change has occurred since 1897 to cause the court to change its view? Probably a recognition of the value of the union shop contract in promoting industrial peace, when the union itself is open and the labor is relatively unskilled. In such cases, the union necessarily must embrace a larger number of workers to "effectuate collective bargaining" and help bring about industrial peace. Under such circumstances, the union shop contract has positive social advantages which were not recognized in 1897 but were tacitly recognized by the court in Williams v. Quill in 1938 .

Where a closed union does have control of the labor supply of a trade requiring special skill, the union shop contract might be an instrumentality of an undesirable monopoly which even the court in Williams $v$. Quill might condemn. But when the labor is relatively unskilled, as in Williams v. Quill, or where the industry is highly competitive, as in National Association $v$. United States, ${ }^{88}$ the union shop contract with an open union is not generally considered as socially undesirable; and it may be expected that an important tendency of courts in such cases will be to restrict strongly the application of "monopoly" to union shop contracts.

In some instances unions enter into unholy alliances with employers,

${ }^{87} 277$ N.Y. I, 9, I2 N.E. (2d) 547, 55I (1938). See The All-Union Shop in the Courts, 6 I.J.A. Bull. $I_{47}\left(\mathrm{I}_{938}\right)$.

${ }^{88}{ }_{263}$ U.S. 403 (I923). 
obtain thereby the union shop contract and other concessions, and assist the employer in a program of price fixing or market control. ${ }^{89}$ The courts have not hesitated in such cases to impose criminal convictions or judgments for damages on participating unions and employers. ${ }^{\circ 0}$ Even though the New York Court of Appeals laid stress on the exemption of unions from the New York anti-trust statute, ${ }^{9 x}$ that court would probably have no difficulty in finding a basis for imposing liability on a union which participated jointly with an employer in an unlawful price-fixing or market-controlling scheme. It should be recalled, however, that not every restriction is an illegal monopoly ${ }^{92}$ and that even complexly restrictive agreements between unions and employers may be held perfectly lawful if deemed to be reasonable and to be for the advancement of productive ends. ${ }^{33}$

4. After the union shop contract is finally held not to be unlawful, its enforcement presents new problems to the courts. It was contended formerly that the union shop contract could not be enforced by injunction because it is a contract for personal services and lacks mutuality; because the union has an adequate remedy at law; and because by dictating the persons who should be employees the court would be exerting undue control over the employer's business. ${ }^{94}$ However, it was effectively answered that the contract is independent of and wholly different from the employee's contract for personal services; that the damages at law are inadequate because by the violation there is not only a loss in wages by the employees but also an immeasurable loss by the union in prestige, standing, and organizational vitality; and that it is to the best interests of

${ }^{89}$ Cummins, The Labor Problem in the United States 307 (1932).

90 Boyle v. United States, 259 Fed. 803 (C.C.A. 7 th I 919 ); Belfi v. United States, 259 Fed. 822 (C.C.A. 3d I9I9); Campbell v. People, 72 Colo. 2I3, 210 Pac. 84x (Ig22); Purington v. Hinchliff, 2I9 Ill. 159, 76 N.E. 47 (I905); Brescia Construction Co. v. Stone Masons Contractors' Ass'n, r95 App. Div. 647, I87 N.Y. Supp. 77 (I921); Falciglia v. Gallagher, I64 Misc. 838,299 N.Y. Supp. 890 (r937), app. dism. C.C.H. Lab. Law Serv. If I8164 (N.Y. S. Ct. Bronx County I938); Standard Engraving Co.v. Volz, 200 App. Div. 758, I93 N.Y. Supp. 831 (rg22); Overland Publishing Co. v. H. S. Crocker Co., I93 Cal. 109, 222 Pac. 8I2 (rg24).

$9 x$ Williams v. Quill, 277 N.Y. I, 10, I2 N.E. (2d) 547, 55I (1938). See Union Exemption from Anti-Trust Act-Contracts Curtailing Competition, 39 Col. L. Rev. 29I (I939).

${ }_{92}$ Clark, Social Control of Business 447 ( 1926$)$.

${ }_{93}$ Nat'l Ass'n v. United States, 263 U.S. 403 (x923); Nat'l Fireproofing Co. v. Mason Builders Ass'n, 169 Fed. 259 (C.C.A. 2 d r9o9); Maisel v. Sigman, I23 Misc. 714, 205 N.X. Supp. 807 (I924).

94 Schwartz v. Wayne Circuit Judge, 217 Mich. 384, 186 N.W. 522 (1922); Schwartz v. Cigar Makers Int'l Union, 219 Mich. 589, I89 N.W. 55 (I922); Stone Cleaning and Painting Union v. Russell, 38 Misc. 513, 77 N.Y. Supp. I049 (1902); see dissent in Schlesinger v. Quinto, 201 App. Div. 487, r94 N.Y. Supp. 40I (rg22). 
society that judicial action restrain violations which would otherwise result in strikes and industrial strife. Furthermore, the judicial use of the sanction of employee reinstatement has now been expressly approved by the United States Supreme Court.95 The courts' general change of attitude toward enforcement of the union shop contract has coincided with a greater willingness to enforce all collective labor agreements. ${ }^{96}$ In the matter of remedy, therefore, the union shop agreement is enforced in the same manner as other collective labor agreements. It has been widely enforced by injunction. ${ }^{97}$ A preliminary injunction will not be issued unless plaintiff's right is clear;98 and statutory restrictions on the issuance of injunctions in labor disputes apply.99 A provision in the contract for arbitration of disputes of interpretation will not bar the injunctive remedy when the employer has breached the entire union shop provision by hiring nonunion employees. ${ }^{x 00}$ The injunction will be issued against parties successor to the employer, particularly if the employer seeks to avoid the union shop agreement by a protean change of entity. ${ }^{\text {Ior }}$ Punishment for contempt will be inflicted not only on the offending corporation, but also on the officer who knowingly violates the injunction. ${ }^{\mathbf{x} 2}$ It is no defense that the

95 NLRB v. Jones \& Laughlin Steel Co., 301 U.S. I, 47 (I937).

${ }_{96}$ Witmer, Collective Labor Agreements in the Courts, 48 Yale L. J. I95 (1938); The Present Status of Collective Labor Agreements, 5I Harv. L. Rev. $5^{20}$ ( $\left.{ }_{93} 8\right)$.

97 Des Moines City R. v. Amalgamated Ass'n, 204 Iowa Ir95, 213 N.W. 264 (I927); Goyette v. Watson, 245 Mass. 577, I40 N.E. 285 (I923); Mississippi Theatres Co. v. Hattiesburg Local Union No. 6I 5, I74 Miss. 439, I64 So. 887 (I936); Schlesinger v. Quinto, 20r App. Div. 487, 194 N.Y. Supp. 401 (1922); Rifkin v. Mandelbaum, xo Law \& Labor I42 (N.Y. S. Ct. r928); Ribner v. Racso Butter and Egg Co., I35 Misc. 6r6, 238 N.Y. Supp. r32 (1929); Roosevelt Amusement Co. v. Empire State Motion Picture Operators Union, I44 Misc. 644, $25^{8}$ N.Y. Supp. 240 (r93o); Suttin v. Unity Button Works, I44 Misc. 784, 258 N.Y. Supp. 863 (I932); Sum v. Independent Retail Fruit Merchants' Ass'n, I44 Misc. 684, 258 N.Y. Supp. 609 (1932); Spivak v. Wankofsky, ${ }_{55}$ Misc. 530, 278 N.Y. Supp. 562 (1935); De Agostina v. Parkshire Ridge Amusements, I55 Misc. 5I8, 278 N.Y. Supp. 622 (r935); In the Matter of Albert, I60 Misc. 237, 288 N.Y. Supp. 933 (I936); American Fur Manufacturers Ass'n v. Associated Fur Coat \& Trimming Manufacturers, I6I Misc. 246, 29I N.Y. Supp. 6Io (I936); Murphy v. Ralph, I65 Misc. 335, 299 N.Y. Supp. 270 (1937); Harper v. Local Union No. 520, Int'l Brotherhood of Electrical Workers, 48 S.W. (2d) ro33 (Tex. Civ. App., 1932).

${ }_{98}^{8}$ Morrin v. Structural Steel Board of Trade, 23I App. Div. 673, 248 N.Y. Supp. 273 (I93I).

${ }_{99}$ Bulkin v. Sacks, $3 x$ Pa. Dist. and Co. 5o, C.C.H. Lab. Law Serv. ๆ $\times 8{ }_{5} 8$ (Pa. Ct. of Com. Pl. Phila. County r938); Tobin v. Shapiro, $3_{2}^{2}$ Pa. Dist. and Co. 29r, C.C.H. Lab. Law Serv. II $\mathrm{I}_{\mathrm{I}} \mathrm{I}^{8}$ (Pa. Ct. of Com. Pl. Dauphin County $\mathrm{I}_{93} 8$ ).

${ }^{100}$ Engelking v. Independent Wet Wash Co., I42 Misc. 510, 254 N.Y. Supp. 87 (x93I).

xox Henry v. Century Shoe Co., I 2 Law \& Labor 7 (Mass. Super. Ct. Essex County I929); Mississippi Theatres Co. v. Hattiesburg Local Union, x74 Miss. 439, x64 So. 887 (I936); Goldman v. Rosenzweig, to Law \& Labor 207 (r928), aff'd 224 App. Div. 8I7 (I928) and 225 App. Div. 669 (rg28). (I932).

${ }^{102}$ Sum v. Independent Retail Fruit Merchants' Ass'n, $x_{44}$ Misc. 684, 258 N.Y. Supp. 609 
employer failed to read or understand the agreement, ${ }^{103}$ that the terms have become onerous since the date of execution, ${ }^{\text {To4 }}$ or that the agreement was entered into under threat of a strike during the busy season. ${ }^{\mathrm{x} 5}$ However, an injunction restraining violation of the agreement will not, in the absence of an express contractual provision, be extended to restrain the employer from moving his plant; ${ }^{\text {ro6 }}$ nor will an injunction issue in a case where the contract requires the employer to hire only union operatives and where there are no union operatives available. ${ }^{\mathbf{1 0} 7}$ The Louisiana Court of Appeals suggested that no damages are suffered by the individual union member who is discharged when the employer replaces union men with non-members in violation of a union shop contract. ${ }^{\mathrm{x} 8}$ Doubtless, the employer had the right to discharge union members for all motives save one, and even for caprice, providing he gave them the two weeks' notice required by the contract in that case. However, since it appeared that they would have been working during the entire term of the contract but for the employer's act in breaching the contract, and since the employer's motive in discharging them was the one motive he had legally bound himself not to accede to, recovery probably should have been allowed.

When a change occurs in the affiliation of employees or in the organizational form of a labor union, courts have determined the effect on the union shop contract by application of the principles covering voluntary associations in general. The national and the state labor relations act have, however, introduced new factors which will be discussed later in detail. ${ }^{\text {rog }}$

5. Once the employer has entered into the union shop contract with a union, he may be subjected to picketing and boycotting by another union, which seeks either to deter the employer from observing or renewing the contract, or to win the affiliations of the employees, or both. Will the courts which sanction the execution of the union shop contract confer on an employer any greater privilege than before against such interference by the competing labor union? The New York Court of Appeals has said that it is preferable to permit such activities, because even though some

${ }^{103}$ Spivak v. Wankofsky, ${ }_{55}$ Misc. 530, 278 N.Y. Supp. 562 (1935).

${ }^{204}$ Schlesinger v. Quinto, 201 App. Div. 487, r94 N.Y. Supp. 4 or (rg22).

${ }^{205}$ Wasserstein v. Beim, 163 Misc. r6o, 294 N.Y. Supp. 439 (1937).

${ }^{106}$ Goldman v. Wile Importing Co., ro Law \& Labor 207 (N.Y. S. Ct. r928), aff'd 225 App. Div. 852 (1929) and 226 App. Div. 728 (r929); Goldman v. Cohen, 222 App. Div. 63r, 227 N.Y. Supp. 3II (1928).

${ }^{107}$ Goyette v. Watson, 245 Mass. 577, I40 N.E. 285 (I923).

${ }^{108}$ Volquardsen v. Southern Amusement Co., 156 So. 678 (La. 1934).

${ }^{109}$ See pp. $47-50$ infra. 
hardships may be inflicted, greater social gain comes from allowing freedom of activity. ${ }^{\text {Iro }}$ Since the New York courts have been among the first to give decisive effect to the social consideration that closed shop contracts based on freedom of organization bring desirable industrial peace, it is understandable that they should take the lead in insisting upon the indispensability of freedom of organization, especially since few specific judicial or statutory safeguards on such freedom used to exist. The New York view permits the new union an equal opportunity with the old in competing for allegiance before the term of the contract has expired. Although there are few decisions, it would seem that the prevailing judicial view will be to grant the employer a higher privilege, on the ground of protecting the executed contracts from interference, ${ }^{\text {III }}$ much as courts used to protect the anti-union contract. ${ }^{\text {II2 }}$ Inferentially, courts may feel that if the union shop contract is designed to secure industrial peace, they should assist its purpose by suppressing picketing and boycotting designed to end the contract or calculated to injure the contracting employer who has executed it. This view is somewhat strengthened by the recent statutory enactments tending to assure freedom of association as a condition precedent to the union shop contract. ${ }^{\mathrm{Ix} 3}$

\section{THE LABOR RELATIONS ACTS REGULATE THE UNION SHOP CONTRACT}

By themselves, courts have found no available rule of law which imposes as a prerequisite to the union shop contract's validity the requirement that the union be the freely designated representative of a majority of the employees involved. Courts have even stated that there is no legal objection to the union shop contract arising from the fact that the union may represent only a minority or even none of the employees. ${ }^{\mathrm{Xr} 4}$ This view has often been of great immediate assistance to employers who have

${ }_{110}$ Stillwell Theatre v. Kaplan, 259 N.Y. 405, I82 N.E. 63 (I932); J. H. \& S. Theatres v. Fay, 260 N.Y. 315 , r83 N.E. 509 (1932); Buy-Wise Markets v. Winokur, 167 Misc. 235, 2 N.Y. S. (2d) 854 (1938); see Church Shoe Co. v. Turner, 218 Mo. App. 516, 279 S.W. 232 (1926).

${ }_{1 x}$ Tracey v. Osborne, 226 Mass. 25, $\mathrm{Ir}_{4}$ N.E. 959 (I9r7); see Wolchak v. Wiseman, $x_{45}$ Misc. 268, 259 N.Y. Supp. 225 (I932).

122 Hitchman Coal \& Coke Co. v. Mitchell, 245 U.S. 229 (I9I7).

${ }^{13}$ See pp. $45^{-50}$ infra.

${ }_{14}$ Schuster v. Int'l Ass'n of Machinists, 293 Ill. App. I77, I93, I2 N.E. (2d) 50, 56 (I937); Jordan's Wearing Apparel v. Retail Sales Clerks Union of New Jersey, 193 Atl. 806, 807 (N.J. Eq. I937); American Furniture Co. v. Int'l Brotherhood of Teamsters, 222 Wis. 338, 370, 268 N.W. 250, 265 (I936); see United Shoe Workers of America v. Wisconsin Labor Relations Board, 227 Wis. 569,279 N.W. 37 (r938). But see Shelley v. Portland Tug \& Barge Co., $5^{8}$ Ore. 377,76 P. (2d) 477 (1938). 
wished to control the other party to the union shop contract, and to conservative, established unions which, before persuading a majority of the employees to join the union, have been able to persuade employers to sign union shop contracts. Nevertheless, courts have often expressed some compunction on this point, and as pointed out above, ${ }^{\mathrm{x} 55}$ their solicitude for the discharged non-member may have been due in some part to a desire to assure free union representation. Recently, two lower courts were able to find in the general language of statutory declarations of policy favoring freedom of association sufficient justification to require that the contracting union represent a majority of the employees. ${ }^{\mathrm{II} 6}$ A change has occurred, however, since the enactment of the National Labor Relations Act.

The National Labor Relations Act ${ }^{\mathrm{Ir} 7}$ marked the imposition of regulatory requirements on the union shop contract designed to assure its development in accordance with national policy. Of course, the act applies only to enterprises affecting interstate commerce. ${ }^{118}$ The purpose of the act expressed in its preamble ${ }^{\mathrm{II} 9}$ is to encourage collective bargaining to the end of promoting industrial peace and increasing the purchasing power of wage earners. Although employers are often tempted to secure industrial peace by union shop agreements with non-representative unions and even sometimes offer tempting wage scales to induce employee acquiescence, it seems clear that over a long period of time the aims of the act can be achieved only by collective bargaining agencies which are based on freedom of association. To this end, the act specifically announces:

Nothing in this act.... shall preclude an employer from making an agreement with a labor organization (not established, maintained or assisted by any action defined in this act as an unfair labor practice) to require as a condition of employment membership therein, if such labor organization is the representative of the employees as provided in section 9 (a) in the appropriate collective bargaining unit covered by such agreement when made..$^{\text {xao }}$

By encouraging collective bargaining, the act stimulates the growth of the union shop; but simultaneously the act regulates the union shop contract by imposing the following prerequisites:

Is See pp. 33-6 supra.

${ }^{136}$ Bowers v. California Milling Co., C.C.H. Lab. Law Serv. If 18292 (Cal. Super. Ct. Los Angeles County I939); Tobin v. Shapiro, 32 Pa. Dist. \& Co. 29x, C.C.H. Lab. Law Serv. If 18138 (Pa. Ct. of Com. Pl. Dauphin County I938).

${ }^{117} 49$ Stat. 449 (1935), 29 U.S.C.A. $\$ \&$ r5I-66 (Supp. 1938).

${ }_{128}$ See NLRB v. Fainblatt, 306 U.S. 6oI (I939).

${ }^{129} 49$ Stat. 449 (r935), 29 U.S.C.A. \& I I (Supp. I938).

${ }^{220} 49$ Stat. $45^{2}$ (I935), 29 U.S.C.A. § I 58 (3) (Supp. I938). 
I. The employer must refrain from establishing, maintaining or assisting the labor organization by any action defined in the act as an unfair labor practice; and

2. The union must be designated "for the purposes of collective bargaining by the majority of the employees in a unit appropriate for such purposes." "2r

The effect of these provisions is to tend to secure freedom of self-expression to workers and to hamper the efforts both of employers who wish to select unions for their employees and of unions which seek recognition from employers without first winning it freely from the employees. Which acts of an employer are unfair labor practices, what is meant by establishing, maintaining, or assisting a labor organization, how a union is designated, and what constitutes an appropriate bargaining unit are subjects more appropriate to a detailed discussion of the National Labor Relations Act. We may observe here that in a number of cases, the National Labor Relations Board has declared union shop contracts unlawful and unenforceable under the act, and has even directed the refund of union dues which employers had deducted from wages and paid over to unions. ${ }^{122}$ The courts may be willing, however, to go farther than the Board in permitting freedom to the employer to select the union of his employees which shall execute the union shop contract. ${ }^{123}$ It should be recalled, that the enforcement of the National Labor Relations Act is vested exclusively in the Board ${ }^{\mathrm{r} 24}$ and that it is only on review of the Board's orders that the courts interpret the requirements as to union shop contracts. Nevertheless, the prevailing trend evidenced by the act may exhibit itself in judicial opinions in other cases as an application of the rules denying enforcement to contracts made under undue influence. Lately, courts have not hesitated to find labor organizations of questioned origin not to have been formed or dominated by the employer, ${ }^{125}$ and there seems to be no good

${ }^{22 x} 49$ Stat. 453 (I935), 29 U.S.C.A. \& 159 (Supp. 1938).

${ }_{122}$ E.g., In the Matter of Highway Trailer Co., 3 NLRiB 59I (1937); In the Matter of Southern Chemical Cotton Co., 3 NLRB 869 (I937); In the Matter of Missouri-Arkansas Coach Lines Co., 7 NLRB I86 (r938); In the Matter of West Kentucky Coal Co., Io NLRB 88 ( 938 ); see NLRB Third Annual Report 88-90 (I939); NLRB v. Nat'l Motor Bearing Co., ro5 F. (2d) 652 (C.C.A. 9th I939).

${ }^{123}$ Cons. Edison Co. v. NLRB, 305 U.S. 197 (1938); Jefferson Electric Co. v. NLRB, 102 F. (2d) 949 (C.C.A. $7^{\text {th }}$ 1939).

${ }^{124} 49$ Stat. 453 (1935), 29 U.S.C.A. $\S$ I60 (a) (Supp. I938).

${ }^{225}$ Hotel, Restaurant \& Soda Fountain Employees v. Miller, 272 Ky. 466, II4 S.W. (2d) 501 (1938); Esco Operating Co. v. Kaplan, I44 Misc. 646, 258 N.Y. Supp. 303 (r932), aff'd 236 App. Div. 704, 259 N.Y. Supp. Ior7 (1932); Henke \& Pillot Co. v. Amalgamated Meat 
reason why courts might not exercise their equity powers to discover employer domination.

Of great importance in recent years since the division in the American organized labor movement has been the question of the effect on the collective labor agreement, and particularly on the agreement for the union shop, of a change of affiliation of a substantial number of union members. ${ }^{\mathrm{x} 26}$ Courts have inclined toward treating the question in accordance with the established rules of law governing voluntary associations. ${ }^{\text {127 }}$ The effect of this attitude will generally be to penalize the withdrawing members and to aid the union named in the contract, since the constitutions of most of the national unions are designed to retain and not to lose locals. ${ }^{128}$ The result is desirable from the standpoint of the officials of the deserted union; and perhaps also generally to the extent that in cases of union shop contracts it will discourage hasty withdrawals from the union. Likewise it is fair to the employer who is interested principally in acquiring the right to a union label on his products. However, it may result in tying workers to a corrupt or ineffectual union from which they wish to free themselves, particularly in cases where union shop contracts are effective for a number of years. Courts which desire to emphasize freedom of organization will therefore place greater emphasis on the employees' choice. One California court declared that the withdrawing and the remaining employees might join in proportionately enforcing the contract. The court stated that each group was a "successor" to the original union, and then correctly said of this complex and somewhat illogical product: "I realize that my conclusions result in a somewhat chaotic condition." ${ }_{\mathbf{2} 29}$ The problem has received such a complex solution from the courts that it should certainly receive the attention of the draftsman when the union shop contract is in preparation, and appropriate provisions should be inserted in the contract to remove doubt as to its status in case of a change of affiliation.

Under the National Labor Relations Act, the character of the problem

Cutters, rog S.W. (2d) ro83 (Tex. Civ. App. r937); Grace Co. v. Williams, 20 F. Supp. 263 (D.C. Mo. I937).

${ }^{126}$ See Effect of Employees' Change of Union Affiliation upon a Closed Shop Contract, 48 Yale L. J. 1059 (I939).

${ }_{227} M$ and $M$ Woodworking Co. v. Plywood \& Veneer Workers, 23 F. Supp. II (D.C. Ore. I938); Mason Manufacturing Co. v. United Furniture Workers, 2 L.R.R. 838 (Cal. Super. Ct. Los Angeles County 1938); Weintraub v. Spilke, I42 Misc. 867, 255 N.Y. Supp. 50 (I93I); World Trading Co. v. Kolchin, x66 Misc. 854, 2 N.Y. S. (2d) 195 (1938).

${ }_{228}$ See, e.g., the provisions involved in $M$ and $M$ Woodworking Co. v. NLRB, IOI F. (2d) 938, 94I (C.C.A. 9th I939).

ז29 Cassetana v. Filling Station Operators Union, I (A) Labor Relations Reference Manual 672 (Cal. Super. Ct. San Francisco County r937). 
is somewhat altered. Each collective labor agreement which covers an enterprise involving interstate commerce and provides for exclusive representation for a union is subject to the statutory requirement, ${ }^{\mathbf{3 0}}$ made without express reference to collective agreements, that only the representative designated by the majority shall be the exclusive representatives of all the employees in the unit. A union which is not so designated cannot be the exclusive representative. Thereby the continuing validity of all collective agreements is affected..$^{3 x}$ The problem is particularly difficult, however, in the case of the union shop contract because of the nature of the union shop requirement. If a majority of the employees working in a union shop change their designation of representatives, their acts may have the effect of (I) transferring the contract to the new union, (2) nullifying the union shop contract, or (3) subjecting the withdrawing employees to discharge by operation of the contract with the old union. Since each union shop contract affected by the act is subject to the statutory requirement of majority designation, perhaps the best solution lies in considering the contract terminated upon the board's certification of a new representative. Theoretically, such a determination could be made very frequently; and the board has declined to fix any time limit. However, the board recently refused to permit an employer to question a certification only seven months after an earlier certification, ${ }^{\mathrm{r} 2}$ and the general tendency seems to be to require approximately a year to elapse after signature of a valid contract or after an earlier certification before the board will consider a new request for certification. ${ }^{133}$ A Pennsylvania court suggested in this connection that one year is "not an unreasonable period during which employees may bind themselves to a fixed compensation and to definite working conditions." ${ }^{34}$ In its report on the proposed amendments to the National Labor Relations Act in April, I937, the board said it would "favor a statute clarifying the status of a contract where a majority of the membership in the contracting labor organization withdraw or shift their allegiance to another organization." ${ }^{25}$

In one proceeding to enjoin unfair labor practices, $M$ and $M W o o d-$ ${ }^{{ }^{30}} 49$ Stat. 453 (1935), 29 U.S.C.A. \& 159 (a) (Supp. $x_{93} 8$ ).

${ }^{13 x}$ See Rice, The Determination of Employee Representatives, 5 Law \& Contemp. Prob. r88, $x_{94-9}$ ( 1938 ).

${ }^{132}$ In the Matter of Whittier Mills Co., I5 NLRB No. 47 (I939).

${ }^{\times 33}$ See, e.g., In the Matter of the Nat'l Sugar Refining Co., Io NLRB I410 (I939); In the Matter of Gross Galesburg Co., I 5 NLRB No. 74 (I939).

${ }_{34}$ Pennsylvania Labor Relations Board v. Red Star Shoe Repairing Co., C.C.H. Lab. Law Serv. II I82I6 (Pa. Ct. of Com. Pl. I938).

${ }^{135}$ Report of the NLRB to the Senate Committee on Education and Labor upon S. Iooo, etc., at 34 (I939). 
working Company v. National Labor Relations Board, ${ }^{136}$ the court believed that the requirements of the act ${ }^{137}$ were met if the union was the representative designated by the majority at the time the contract was executed. The board had ordered reinstatement of some discharged employees. The employer had sought to justify the discharges on the ground that the employees had abandoned the local union affiliated with the Brotherhood of Carpenters and Joiners (A.F. of L.), with whom the employer had a union shop contract, and had joined a local union affiliated with the International Woodworkers of America (C.I.O.). The board had found that the old local union legally severed its affiliation with the Brotherhood and that the employer was guilty of an unfair labor practice in refusing to hire members of the new local. The board suggested that the union shop contract had either expired as a result of the severance of affiliation or passed to the new local as successor to the old local. Under either possibility, the board pointed out, the question of the contract's validity did not have to be decided..$^{\mathbf{3} 8}$ The majority of the court disagreed with the Board and found that under the laws governing voluntary associations, the withdrawing employees had failed to effect a proper dissolution of the first local union and that the union shop contract was therefore still in force and binding on the employer. The dissenting judge said that the withdrawing employees had effected a legally proper dissolution. None of the opinions discussed the effect of the continuing requirement of the act that the representatives of the majority should be the exclusive representatives of all the employees. ${ }^{\mathrm{r} 9}$ The court might have stressed the fact that the second union had not obtained a formal certification from the board and that the employer was justified in continuing to observe the contract at least until he received notice of certification of a new representative of the employees.

One court suggested that the newly certified bargaining agency succeeds to all the rights of the preceding bargaining agency to the enforcement of an existing collective labor agreement. ${ }^{40}$ This result is simple, but it seems justified neither by the law of voluntary associations nor by the National Labor Relations Act; yet it may represent a practical combination of contractual stability and organizational freedom. The

${ }^{236}$ Ior F. (2d) 938 (C.C.A. 9th 1939 ).

${ }^{x 37} 49$ Stat. 453 (1935), 29 U.S.C.A. \& 159 (a) (Supp. 1938).

${ }^{23} 3^{8}$ In the Matter of $M$ and $M$ Woodworking Co., 6 NLRB 372 ( $(938)$.

${ }^{239} 49$ Stat. 453 ( 1935 ), 29 U.S.C.A. $\S$ I59 (a) (Supp. r938); for a detailed criticism of the opinion, see Effect of Employees' Change of Union Affiliation upon a Closed Shop Contract, 48 Yale L. J. ro59 (r939).

${ }^{140}$ Brisbin v. E. L. Oliver Lodge, ${ }_{34}$ Neb. ${ }_{517}, 279$ N.W. ${ }_{277}$ (1938). See Rice, op. cit. supra note $\mathrm{x}_{3} \mathrm{r}$, at $\mathrm{x} 88, \mathrm{x}_{99}$ for a suggestion of the difficulties involved. 
problem may be resolved shortly by the Supreme Court in a pending proceeding. ${ }^{\text {Itr }}$

Since the enactment of the National Labor Relations Act in July, I938, six states have passed labor relations acts which affect the union shop contract. The statutes of Massachusetts, ${ }^{12}$ New York, ${ }^{143}$ and Utah ${ }^{144}$ have the same effect as the National Labor Relations Act on the union shop contract. The Minnesota statute ${ }^{\mathrm{x} 45}$ has substantially the same effect. In Pennsylvania and Wisconsin, however, new requirements have been added. The Pennsylvania statute was at first the same as the National Labor Relations Act but now requires as a condition precedent to the validity of the union shop contract that the union refrain from denying membership to any employee of the employer at the time of making the agreement, excepting only employees employed in violation of any previous agreement with the union..$^{16}$ In Wisconsin, the union shop contract is permitted only if at least three-fourths of the employees in a collective bargaining unit vote in favor of the contract by secret ballot in a referendum conducted by the Wisconsin Labor Relations Board; and furthermore, any union shop contract may be declared terminated by the board if the board finds that the union has unreasonably refused to receive any employee of the employer as a member. ${ }^{147}$ These statutes are noteworthy since they represent an extension of the regulation commenced by the National Labor Relations Act. But while the National Labor Relations Act seems designed to facilitate the union shop contract and safeguard organizational freedom, the Wisconsin statute in its elaborate referendum requirement seems designed more to make the union shop contract extremely difficult for unions to attain than to safeguard freedom of organization. To the extent that it represents a return to the prevailing views of the past, the Wisconsin statute can be termed reactionary; and it is possible that the trend of the next years may be reactionary.

\section{TV. FIELDS OF UNEVEN DEVELOPMENT}

In certain specific fields, the development of judicial or statutory treatment of the union shop contract has differed markedly from the doctrine developed in the general consideration of the contract. The presence of exceptional factors leads in each case to a deviation which serves to emphasize the course of the general trend of judicial decisions. Thus, special doctrines have arisen concerning the union shop contract in the following cir-

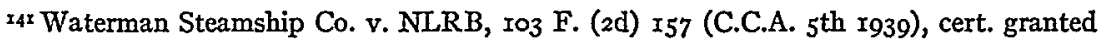
Oct. 9, 1939 .

${ }^{142}$ Mass. Ann. Laws (I938) c. I50 (A), §4 (3). $\quad$ I45 Minn. L. I939, c. 440 §2 (c).

${ }^{143}$ N.Y. Labor Law $\$ 704(5)$.

${ }_{146}^{6} \mathrm{~Pa}$. L. $1939,293$.

I44 Utah Rev. Stat. (1937) § 49-I-9 (3).

147 Wis. L. I939, C. $57 \S$ III.o6.
} 
cumstances: ( $\mathrm{r}$ ) when it is proposed to cover governmental employees, (2) when it is proposed to cover railroad employees, (3) when it is proposed under statutes indicating disapproval of the union shop, and, (4) potentially, during a war.

I. In its own capacity as an employer, the state seems to favor itself over private employers. While private employers are generally no longer judicially protected from the union shop contract, the state continues to give itself such protection. Civil service laws which govern in detail the employment and discharge of state employees have been deemed incompatible with a contract which would require union membership as a condition of continuing employment. Civil service employees have relatively great security of tenure and possibility of promotion, and the incentives to industrial warfare are not usually present to the same degree as in private employment. Thus, when at the request of a union the United States Government Printer discharged an employee solely for non-membership in the union, the United States Civil Service Commission ordered his reinstatement. ${ }^{148}$ A similar position against the union shop has been taken by the United States Maritime Commission, ${ }^{49}$ and apparently the Tennessee Valley Authority which is required to select employees "on the basis of merit and efficiency," ${ }_{150}$ also considers itself unauthorized to execute a union shop contract. ${ }^{15 x}$

The government does not require the voluntary peace machinery which the union shop tends to establish. The greater security of the permanent government employee provides a guarantee of peaceful relations which is absent in most private industries; and, if industrial warfare occurs, the government has greater combative resources than the private employer. Governmental functions are considered too essential to permit stoppages. Nevertheless, with the great extension of government into fields formerly reserved to private enterprise, it might not be untimely to give the government authority to enter into union shop contracts where they seem desirable or at least to distinguish between governmental and proprietary activities. This result is suggested by a recent Washington statute permitting municipalities which own public utilities to enter into collective agreements with unions representing the employees engaged in the construc-

${ }^{{ }^{8} 8} \mathrm{H}$. Doc. $644,5^{8 \text { th }}$ Cong. $2 \mathrm{~d}$ Sess., Twentieth Annual Report of the United States Civil Serv. Com'n $147-50$ (Ig04); Series XXIX, op. cit. supra note 2; Stockton, Closed Shop in American Trade Unions 46-8 (IgIr).

149 Statement of United States Maritime Com'n, May Io, I939, 4 L.R.R. 740 (1939).

${ }^{150} 48$ Stat. 63 (1933), I6 U.S.C.A. $\$ 83$ (c) (Supp. I938).

${ }^{15 x}$ Address of Joseph Padway, general counsel, to American Federation of Labor, N.Y. Times, col. I, p. I7 (Oct. 5, I939). 
tion, maintenance, or operation of public utilities. ${ }^{152}$ The contracts may concern wages, hours, and "conditions of labor in such employment." The statute does not by its terms prohibit the union shop contract.

The court will protect the right of a municipal corporation to maintain the closed anti-union shop; and governmental employers have been held to have the unqualified right to discriminate against employees for union membership. ${ }^{153}$ Under statutes requiring purchases to be made at the lowest obtainable prices and from the lowest bidders, municipal corporations have been held to be without authority to require the union label or the union shop from the contractors with whom they deal. ${ }^{154}$ A municipal corporation was, however, permitted to require the union shop under a statute authorizing it to award the contract to the lowest "responsible" bidder; ${ }^{\text {;5s }}$ and a dictum in a recent New York case ${ }^{\mathrm{rs} 6}$ seems to be the only other judicial evidence of a possible change of attitude. Municipal corporations have been uniformly held to be without authority to enter into the union shop contract. ${ }^{157}$ The courts point out that the execution of a union shop contract would constitute not only a class discrimination but also an unlawful delegation of the prerogatives of government. ${ }^{x 88}$ That the encroachment on prerogatives or the discrimination might be reasonable is rejected. Courts are applying to the state the rules which they evolved for private employers a half century ago. It appears, however, that despite their freedom from the duty to bargain collectively, some municipal corporations have extended exclusive recognition to unions of their employees. ${ }^{159}$ The union shop may be establishing itself in fact and may attain judicial recognition in this field as well.

2. In the railroad field the union shop contract is prohibited by statute.

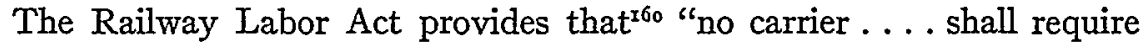
any person seeking employment to sign any contract or agreement prom-

rs2 Wash. Rev. Stat. Ann. (Remington, Supp. I939) $\$ 8966-5$.

${ }_{153}$ People ex rel. Fursman v. Chicago, 278 Ill. 3 18, 116 N.E. $5^{8}$ (I9I7); Seattle High School Chapter No. 200 v. Sharples, $x 59$ Wash. 424, 293 Pac. 994 (I930).

${ }^{{ }_{54}} 3$ McQuillin, Municipal Corporations $\S 1305$ (2d ed. 1928); Lewis v. Board of Education, I39 Mich. 306, I02 N.W. 756 (I905); see Iro A.L.R. I406 (1937).

${ }^{55}$ Pallas v. Johnson, roo Colo. 449, 68 P. (2d) 559 (1937).

${ }^{156}$ Amalithone Realty Co. v. New York, I62 Misc. 715, 295 N.Y. Supp. 423 (I937), aff'd 25 I App. Div. 450, 297 N.Y. Supp. 262 (1937).

${ }^{557}$ Adams v. Brennan, $x_{77}$ Ill. 194,52 N.E. $3{ }^{14}$ (I898); Fiske v. People ex rel. Raymond, 188 Ill. 206,58 N.E. 985 (x900).

${ }^{158}$ See Fuller, Legal Problems of Municipal Labor Relations, 34 Municipality 49 (I939); I McQuillin, Municipal Corporations $\$ 393$ (2d ed. Ig28).

${ }^{59}$ Grennan, The Unionization of Municipal Employees, The American City 97 (r937).

${ }^{{ }^{600}} 48$ Stat. 1186 (r934), 45 U.S.C.A. $\S$ I52, fifth (Supp. 1938 ). 
ising to join or not to join a labor organization." Although the Supreme Court has not construed this provision, it has been accepted by employer and employed as prohibiting union shop contracts. There are factors which compensate the railroad brotherhoods for the loss of the possibility of the union shop. The brotherhoods have finally won substantially complete acceptance as collective bargaining agencies. When they are chosen by a majority of the employees, their collective agreements made by the majority-chosen representatives are binding on all employees $;{ }^{26 x}$ working conditions approach uniformity on all lines; and seniority provisions approximate the security provisions of civil service statutes. ${ }^{162}$ The brotherhoods believe that they require the union shop contract neither for the prestige of maturity nor for freedom from attack on their organizations. Furthermore, the handling of contested grievances established by the Railway Labor Act before the National Adjustment Board ${ }^{163}$ has been placed largely in joint boards selected by the carriers and the established railroad brotherhoods ${ }^{164}$ and the grievance procedure has been informally closed to employees who are not members of the recognized brotherhoods. ${ }^{165}$ Thus the brotherhoods have obtained an important organizational benefit of the union shop, namely, exclusive control of effective grievance procedure. Congress has given the railroad companies, in their capacity as public utilities enjoying relatively little competition among themselves, the same protection from the union shop contract which it accords to the government, but has concomitantly provided by statute for the growth of substantial collective bargaining agencies which can achieve the industrial peace generally associated with the successful union shop contract.

3. Statutes supposedly designed to advance organizational freedom of workers may be so worded as to require or permit courts to hold that the union shop contract is illegal. For example, a California statute provides ${ }^{166}$ that "Every promise made.... between any employee or prospective employee and his employer . . . . is contrary to public policy if either party thereto promises .... to join or to remain a member of a labor organization or not to join or remain a member of an employer organization." A California appellate court held that the statute made the union shop

${ }^{161} 48$ Stat. 1186 (1934), 29 U.S.C.A. \& $5_{52}$ (4) (Supp. 1938).

${ }_{162}$ Cummins, The Labor Problem in the United States 306 (I932).

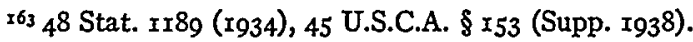

364 Tbid.

r65 Spencer, The National Railroad Adjustment Board, 8 Univ. Chi. Studies in Bus. Administration No. 3 , at 39 ( $\left.\mathrm{I}_{93} 8\right)$.

${ }^{166}$ Cal. Labor Code (Deering, r937) § 921. 
contract unlawful ${ }^{167}$ and enjoined a union from picketing in its attempt to obtain the union shop contract. On rehearing ${ }^{168}$ the court stated that the statute permits the employer to enter into a contract to employ only union members, but not if the contract is in violation of the bargaining rights of existing employees. The court implies either that the union named in the union shop contract must be the unanimous choice of the employees or that the employer may adopt the Massachusetts device ${ }^{\mathrm{Ig}}$ of first discharging all employees and then hiring only union members. The decision might well be classified with other decisions prohibiting picketing for the union shop where no employees are members. ${ }^{170}$ Nevertheless, the California statute and similar statutes in other states ${ }^{17 x}$ may induce courts to outlaw the union shop contract entirely or require unanimous approval of all employees as a condition precedent to its validity. A similar result might conceivably be reached under state statutes prohibiting agreements not to become or remain a member of a labor organization, ${ }^{172}$ since a union shop requirement that an employee remain a member of a specified union might inferentially be construed to be an agreement that he refrain from becoming a member of a rival union. The similar National Industrial Recovery Act, which provided"73 that "no employee .... . shall be required as a condition of employment to . . . . refrain from joining . . . . a labor organization of his own choosing," and was authoritatively hailed in labor circles because it cleared "away obstacles to organization," 774 was promptly interpreted by some courts to outlaw the union shop contract. ${ }^{.75}$ It might be

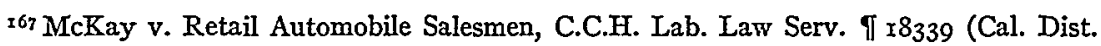
Ct. of App. 1939); see Renzel v. Warehousemen's Union, C.C.H. Lab. Law Serv. II I8340 (Cal. Dist. Ct. of App. I939); Smith Metropolitan Market Co. v. Lyons, C.C.H. Lab. Law Serv. II I834 (Cal. Dist. Ct. of App. 1939).

${ }^{168}$ McKay v. Retail Automobile Salesmen, C.C.H. Lab. Law Serv. If $x 8_{362}$ (Cal. Dist. Ct. of App. I939).

${ }^{66}$ See p. 36 supra.

170 Particularly since at the same time the court permitted picketing for the union shop by a union counting as members nearly half the workers in the enterprise, Boyd v. Lumber, Mill \& Cabinet Workers' Union, 4 L. R. R. 493, C.C.H. Lab. Law Serv. If $183_{3} 62$ (Cal. Super. Ct. Los Angeles County I939).

${ }^{x 71}$ E.g., Colo. Stat. Ann. (Michie, I935) c. 97, $\$ 77$ (A); La. Gen. Stat. Ann. (Dart. I932) tit. 34, C. Io, § 4380; La. Gen. Stat. Ann. (Dart, Supp. I937) § 438x2; Md. Ann. Code (Flack, Supp. 1935), art. roo, $\$ 66$; Nev. Comp. Laws (Hillyer, r929) § ro473; see Perry Truck Lines v. Int'l Brotherhood, 5 L.R.R. I63 (Colo. Denver City Dist. Ct. I939).

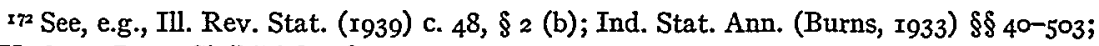
N.Y. Cons. Laws Civil Rights $\S \mathrm{I} 7$.

${ }^{173} 48$ Stat. $\mathrm{r}_{98} 8$ (1933), ${ }_{5}$ U.S.C.A. $\$ 707$ (A) (1939).

${ }^{174} 40$ American Federationist 678 (I933).

${ }_{75}$ Drake Bakeries Co. v. Bowles, 3 I Ohio N.P. (N.S.) 425 (I934); Effect of Section 7 (a) of N.I.R.A. on the Validity of a Closed Union Shop Contract, 44 Yale L. J. Io67 (I935). 
argued that while the statutes forbid certain agreements between employer and employee they do not apply to agreements between employer and labor organization; but if the labor organization is considered to be the representative of the employees, the statutes would probably apply. Similar problems arose under the Weimar Constitution of the German Republic which states: "Freedom of association . . . . is guaranteed for everyone and for all occupations. All agreements and measures which attempt to limit or impede this freedom are contrary to law."176 The courts held that the constitutional guarantee of freedom of organization included freedom from organization; and a majority of the decisions held that a non-union workman had a right of action against a union for damages if he were prevented by a union shop contract from finding work over an unreasonably large area; but not if the union members refused to work with him on account of a serious grievance against him. ${ }^{177}$ It would seem that courts will be quick to find in statutes a legislative intent to restrict the legality of the union shop contract, even though the legislative body may have appeared clearly to be acting to increase workers' freedom to organize.

4. The participation of the United States in a war would undoubtedly have its effect on the union shop contract. Paramount military necessity would demand uninterrupted industrial production, and, while existing union shop contracts might not be declared unenforceable, each industrial worker would become a "rear rank soldier," ${ }_{178}$ and all stoppages or strikes for the union shop contract as well as other purposes would be subject to deterrent measures by the state. During the war of I9I 7-I9r8, the National War Labor Board adopted the following principles governing the union shop:

In establishments where the union shop exists, the same shall continue. . . . .

In establishments where union and non union men and women now work together and the employer meets only with employees or representatives engaged in said establishment, the continuance of such conditions shall not be deemed a grievance. This declaration, however, is not intended in any manner to deny the right, or discourage the practice of the formation of labor unions .... nor to prevent the War Labor Board from urging . . . improvement of their situation in the matter of wages, hours of labor, or other conditions, as shall be found desirable from time to time.179

Furthermore, the need for workers in industry might well be great enough to cause specified exceptions to be made to union shop contracts where ex-

${ }^{136}$ Article ${ }_{59}$, quoted in Fuchs, Collective Labor Agreements in German Law, $x_{5}$ St. Louis L. Rev. I (r929).

${ }_{77}$ Lehmann, Collective Labor Law under the German Republic, Io Wis. L. Rev. 324, 326 (I935).

${ }^{278}$ Alvin Johnson, War Economics, I5 Encyc. Soc. Sci. 342 (1935).

${ }^{179} 5$ L.R.R. ${ }_{448}$ (1939). 
ceptions would be expedient. The closed union might find it difficult to keep itself closed. Basically, the value of the union shop as a measure of industrial peace would be much less than the power of the state to enforce industrial peace by external pressure, coupled with the patriotic willingness of the population to forego acts of industrial strife during the war.

Because the union shop contract directly affects the relative bargaining strength of worker and employer, the development of the judicial attitude toward it affords an excellent example of the functioning of courts as instruments of social control of property relationships. Recent events indicate that legislative enactment may play an increasing regulatory role. In the last analysis, however, under the present form of government, it may be expected that the courts, whose attitudes have been traced in this article, will continue to exercise substantial control over the future evolution of the union shop contract.

\section{NOTE ON FORMS OF UNION SHOP PROVISIONS}

An excellent collection of representative union shop provisions from collective agreements is found in Provisions for Employment of Union Members in Collective Agreements, 33 Monthly Lab. Rev. 869 (I93 I). Additional examples of the union shop provision can be found in Trade Agreements I923-4, Bull. of the U.S. Bureau of Lab. Statistics No. 393 (I925); Trade Agreements I925, Bull. of the U.S. Bureau of Lab. Statistics No. 4 I9 (rg26); Trade Agreements 1926, Bull. of the U.S. Bureau of Lab. Statistics No. 448 (I927); Trade Agreements I927, Bull. of the U.S. Bureau of Lab. Statistics No. 468 (I928) (at page 325 appears an index to the union shop provisions). A description of union shop provisions in current use is found in Closed Shop and Checkoff in Union Agreements, 49 Monthly Lab. Rev. 830 (I939).

The following union shop contract provisions are presented for the purpose of clarifying the discussion in this article. The union shop contract provision contained in a contract executed by the Bakery and Confectionery Workers International Union of America is illustrative of the provision in use where the union has control of employment. It reads:

"I, the undersigned, agree to observe the following conditions:

"I. To employ only such bakers who are members in good standing of Local Union No. 77 .

"2. To secure the same through the employment office of said Local Union No. 77," Trade Agreements r927, Bull. of the U.S. Bureau of Lab. Statistics No. 468, at I3 (I927).

The union shop contract provision under scrutiny by the court in the case of Williams v. Quill, 277 N.Y. I, 4, I 2 N.E. (2d) 547,548 (1938), reads:

"The parties of the first part will not, during the term of this agreement, employ any employee in the groups represented by parties of the second part to which this agreement applies who is not, or who does not, within one month after his employment, become and remain a member in good standing of the Transport Workers Union of America; and all present employees of the groups to which this agreement applies 
who are not now members of the Transport Workers Union of America shall become members within thirty days of the date of this agreement and remain members in good standing."

The following provision contains elaborate regulations to protect the employer and the prospective employee from suffering any penalty in the event that the union refuses to accept a new employee into membership:

"All employees in the classes governed by this agreement shall, as a condition of continued employment, be members in good standing of the Brotherhood of Railroad Trainmen; provided, however,-

(I) Employees in service May I, I938, who are not members shall, if acceptable to the Brotherhood, become members within thirty days from May I, I938, or be automatically removed from service.

(2) Employees in service May I, r938, who are not members and who are rejected for membership by the Brotherhood shall lose no eligibility as employees as a result of such rejection.

(3) Employees who are members and who may be expelled from membership for any cause other than non-payment of dues shall lose no eligibility as employees as a result of such expulsion unless mutually agreed otherwise by the management and the Committee," Agreement between Hudson and Manhattan Railroad Company and Brotherhood of Railroad Trainmen, 2 L.R.R. 604 (I938).

The following is an example of a simple preferential union shop provision:

"In order to secure careful and competent fellow servants and to diminish so far as possible the risks and dangers incident to those engaged in the art of photo-engraving, the employing photo-engravers of Boston agree that in their employment of journeymen and apprentices they will give preference to the members of the Boston PhotoEngravers Union, No. 3, I.P.E.U., by notifying the union officials when additional journeymen or apprentices are needed. If the union cannot furnish and supply competent help, the employer may secure such help from other sources," Folsom v. McNeil, 235 Mass. 269, 270, I26 N.E. 479 (I920).

The following preferential union shop provision is the standard provision used by the Amalgamated Clothing Workers of America:

"It is agreed that the principle of the preferential shop shall prevail, to be applied in the following manner:

"Preference shall be applied in hiring and discharge.

"Whenever an employer needs additional workers he shall first make application to the union, specifying the number and kinds of workers needed.

"The union shall be given a reasonable time to supply the number of workers required, and if unable for any reason to furnish them the employer shall be at liberty to secure them in the open market as best he can.

"In the like manner the principle of preference shall be applied in the case of discharge.

"Should it at any time become necessary to reduce the number of workers, the first ones to be dismissed shall be those who are not members of the union. In all such cases the best efforts shall be mutually exerted to harmonize the interests of both parties," Trade Agreements 5925 , Bull. of the U.S. Bureau of Lab. Statistics No. 4r9, at 77 (I926). 